\title{
EFFECT OF 6-ETHYL-3-( $H$-TETRAZOL-5-YL)CHROMONE (AA-344) ON THE IMMEDIATE AND DELAYED HYPERSENSITIVITY REACTIONS
}

\author{
Hisashi KURIKI, Taketoshi SAIJO, Yasuko ASHIDA \\ and Yoshitaka MAKI \\ Medicinal Research Laboratories, Central Research Division, \\ Takeda Chemical Industries, Ltd., Yodogawa-ku, Osaka 532, Japan
}

Accepted May 2, 1979

\begin{abstract}
Effects of 6-ethyl-3-(1H-tetrazol-5-yl)chromone (AA-344) on the experimental models of the type I-IV allergic reactions were studied in comparison with those of disodium cromoglycate (DSCG), dexamethasone and other agents. AA-344 showed inhibitory effects on the homologous passive cutaneous anaphylaxis and the passive systemic anaphylaxis in guinea pigs. However, it had only a slight or little effect on the Forssman shock in guinea pigs, the complement-dependent cytolysis of mast cells in rats, the Arthus reaction in guinea pigs and the tuberculin reaction and the contact sensitivity in mice. DSCG was less effective, using these experimental models. Dexamethasone showed a suppressive effect on the type III and IV allergic reactions. The results indicate that AA-344 selectively suppresses the type I allergic reaction.
\end{abstract}

We previously reported that 6-ethyl-3-(1H-tetrazol-5-yl)chromone (AA-344) by either i.v. or p.o. administration markedly suppressed the IgE-mediated hypersensitivity due to inhibition of the release of chemical mediators from the mast cells $(1,2)$. The mode of action of AA-344 in vivo and in vitro on the type I allergic reaction, is similar to that of disodium cromoglycate (DSCG) $(3,4)$.

The inhibitory effect of DSCG on the late asthmatic reaction provoked by inhalation of antigen in patients with asthma, which is classified as the type III allergic reaction $(3,5)$, was reported by some groups $(5,6)$, while such could not be confirmed by another group (7). There is apparently no documentation concerning the effect of DSCG on the experimental model of type III allergic reaction in animals. The present study was an attempt to determine whether AA-344 or DSCG, an inhibitor of chemical mediator release from mast cells, has a suppressive effect not only on type I allergic reaction but also on the type II, III and IV allergic reactions, as compared with effects of dexamethasone and antihistamines, in experimental models.

\section{MATERIALS AND METHODS}

Animals: The animals used were male JCL:ICR mice $(25-31 \mathrm{~g})$, male C57BL/6 mice (21-34 g), male BALB/c mice (19-27 g), male Sprague-Dawley rats (250-350 g), Hartley guinea pigs of either sex $(280-450 \mathrm{~g})$ and male albino rabbits $(2.5-4.0 \mathrm{~kg})$.

Chemicals: The following chemicals were used: bovine- $\gamma$-globulin (BGG, Wako), bovine serum albumin fraction V (BSA, Wako), egg albumin (EA, Difco), Freund's complete 
adjuvant (FCA, Difco), Freund's incomplete adjuvant (FIA, Difco), killed Bordetella pertussis (Takeda), killed Mycobacterium tuberculosis Aoyama B strain (Tokyo University), purified protein derivatives of tuberculin (PPD, Nippon BCG), sheep red blood cells (Nihon Seibutsuzairyo Center), promethazine $\mathrm{HCl}$ (Yoshitomi), cyproheptadine $\mathrm{HCl}$ (Merck), dexamethasone phosphate (Takeda), disodium cromoglycate (DSCG, Intal ${ }^{\circledR}$, Fisons). AA-344 and diphenhydramine were synthesized in the Takeda Chemical Labs. Benzyl-penicilloyl$\mathrm{BGG}\left(\mathrm{BPO}_{50} \mathrm{BGG}\right)$ and benzyl-penicilloyl-BSA $\left(\mathrm{BPO}_{32} \mathrm{BSA}\right)$ were prepared according to the method of Horiuchi and Shibata (8).

Homologous passive cutaneous anaphylaxis (PCA) in guinea pigs: Guinea pig anti$\mathrm{BPO}_{50} \mathrm{BGG}$ antisera containing IgE-like or IgG antibody were prepared according to the method of Levine et al. (9). PCA titers for the IgE-like and IgG antibodies were 1:64 and $1: 128$, respectively. Guinea pigs were sensitized passively by giving intradermally (i.d.) $0.05 \mathrm{ml}$ of the 16-fold diluted antiserum containing IgE-like antibody on the left side of the back. Eight days later, these animals were also sensitized by i.d. administration of the 32-fold diluted antiserum containing IgG antibody, on the right side of the back. The PCA was induced by an i.v. challenge with $1 \mathrm{mg}$ of $\mathrm{BPO}_{32} \mathrm{BSA}$ and $10 \mathrm{mg}$ of Evans blue dissolved in $1 \mathrm{ml}$ of a physiological saline $3 \mathrm{hr}$ after the sensitization with IgG. The animals were sacrificed by bleeding $30 \mathrm{~min}$ after the challenge of the antigen and the skin was exfoliated. The intensity of PCA was estimated by measuring the area of the dye-stained wheal, as a product $\left(\mathrm{mm}^{2}\right)$ of the longest and correspondingly perpendicular diameters.

Heterologous PCA in guinea pigs: Rabbit anti-EA antiserum (anti-EA) was prepared according to the method of Koda et al. (10). Groups of 5 guinea pigs were sensitized by giving i.d. $0.05 \mathrm{ml}$ of the 100 -fold diluted antiserum. Three hr later the animals were challenged i.v. with $5 \mathrm{mg}$ of EA and $10 \mathrm{mg}$ of Evans blue.

Passive systemic anaphylaxis (PSA) in guinea pigs: Groups of 16-27 female guinea pigs were passively sensitized by giving i.v. $0.2 \mathrm{ml}$ of the rabbit antiserum described above. Twenty-four hr later the PSA was provoked by administering i.v. the lethal dose $(0.51 \mathrm{mg} /$ $\mathrm{kg}$ ) of EA calculated according to the method of Uda (11). The severity of the PSA shock was graded on the following scales: symptom I, nose licking and rubbing, fur ruffling and weakness due to diminished muscle tone; II, labored breathing, sneezing or coughing, retching and micturition; III, defecation, convulsion, prostration and death.

Active systemic anaphylaxis (ASA) in mice: Groups of 19-20 male JCL:ICR mice were sensitized by giving i.p. $1 \mathrm{mg}$ of EA and $2 \times 10^{10}$ organisms of killed Bordetella pertussis according to the method of Greig et al. (12). Fifteen days after the sensitization, the ASA was provoked by giving i.v. $1 \mathrm{mg}$ of EA and the mortality was recorded $30 \mathrm{~min}$ later.

Passive Schultz-Dale reaction in guinea pig ileum: Isolated guinea pig ileum of about $10 \mathrm{~cm}$ was incubated with rabbit anti-EA (containing $100 / \mathrm{g}$ antibody nitrogen) in $10 \mathrm{ml}$ of Tyrode's solution at $37^{\circ} \mathrm{C}$ for $1 \mathrm{hr}$. The sensitized ileum was suspended in a 20-ml bath containing the Tyrode's solution warmed at $37 \mathrm{C}$ and aerated. For observation of the passive Schultz-Dale reaction, the contractile response of the ileum to antigen ( $2 \mathrm{mg}$ of EA) was recorded isotonically with a resting tension of $0.5 \mathrm{~g}$. The response to histamine 


\section{$\left(2.5 \times 10^{-i} \mathrm{M}\right)$ was also determined as standard.}

Hemolysis of sheep red blood cell (SRBC) caused by rabbit anti-Forssman antigen antiserum and complement (in vitro) and Forssman shock in guinea pigs (in vivo): Forssman antigen and rabbit anti-Forssman antigen antiserum were prepared according to the method of Nishioka (13). In vitro: complement-dependent hemolysis of SRBC was determined by the method of Mayer (14). In vivo: Forssman shock in guinea pigs was provoked by giving i.v. $0.3 \mathrm{ml}$ of the antiserum. The anaphylactoid symptoms observed within $3 \mathrm{~min}$ after injection were weakness, labored breathing, snivelling, prostration and death. Complement activity (CH50: $50 \%$ hemolytic unit of complement) in the serum of guinea pigs before the injection of the antiserum and immediately after death was determined according to the method of Mayer (14).

Complement-dependent cytolysis of rat peritoneal mast cells: Peritoneal cells were harvested from the peritoneal cavity of rats and the mast cells (RMC) were purified according to the method of Sullivan et al. (15), and rabbit anti-RMC antiserum (rabbit anti-RMC) was prepared by the method of Yiu and Froese (16). Experimental procedures of the complement-dependent cytolysis of the RMC were performed as described by Valentine et al. (17) as follows. In vitro: purified RMC (10 cells) was sensitized with $1 \mathrm{ml}$ of the 100 -fold diluted anti-RMC for $15 \mathrm{~min}$ at $37^{\circ} \mathrm{C}$. The sensitized RMC $\left(10^{5}\right.$ cells $)$, rinsed and suspended in a mast cell medium (MCM) (15), was incubated with $0.1 \mathrm{ml}$ of the dialysed normal rabbit serum as a source of complement for $60 \mathrm{~min}$ at $37^{\circ} \mathrm{C}$ in a total volume of $1 \mathrm{ml}$. After centrifugation, histamine in the supernate was determined by the fluorometric method of Shore et al. (18). Lactate dehydrogenase (LDH) activity was determined using the $\mathrm{LDH}_{\mathrm{B}}$ Test Wako kit. The degree of cytolysis of RMC was determined by a staining test with trypan blue (17). In vivo: rats were given i.p. $1 \mathrm{ml}$ of the 30 -fold diluted rabbit anti-RMC. Four hr later, the peritoneal cells were harvested from the rat peritoneal cavity. Total histamine content in the peritoneal cells was used as a parameter of the cytolysis of RMC in vivo.

Arthus reaction in guinea pigs: The passive Arthus reaction was induced according to the method of Benacerraf and Kabat (19). Male guinea pigs were given i.v. $1.1 \mathrm{ml}$ of rabbit anti-EA ( $1 \mathrm{mg}$ of antibody nitrogen) and, immediately thereafter, given i.d. into both flanks $0.2 \mathrm{ml}$ of a EA solution ( $0.07 \mathrm{mg}$ of antigen nitrogen) or saline. The intensity of the reaction was indicated in the legend of Table 6.

Tuberculin reaction in mice: Male C57BL/6 mice were sensitized by administering s.c. an emulsion of $0.05 \mathrm{ml}$ of killed Mycobacterium tuberculosis in saline $(500 \mu \mathrm{g})$ and $0.05 \mathrm{ml}$ of FIA. Fourteen days later, the mice were challenged with $5 \mu \mathrm{g}$ of PPD dissolved in $0.04 \mathrm{ml}$ of distilled water into left footpad. The thickness of the right footpad injected with saline and the left footpad injected with PPD was measured with a Dial Thickness Gauge (Peacock) $24 \mathrm{hr}$ after the challenge.

Contact sensitivity to 2,4-dinitro-I-fluorobenzene (DNFB) in mice: Contact sensitivity to DNFB was tested according to the method of Phanuphak et al. (20). Male BALB/c mice were sensitized by applying $20 \mu \mathrm{l}$ of $0.5 \%$ DNFB in acetone-olive oil $(4: 1)$ on the shaved skin 
surface of the abdominal wall for two days. Five days after the second sensitization, the mice were challenged with application of $10 \mu \mathrm{l}$ of $0.2 \%$ DNFB on the dorsal surface of each ear. The ear thickness was measured by using the Dial Thickness Gauge immediately before and $24 \mathrm{hr}$ after the challenge.

Statistical analysis: The values obtained were expressed as means \pm standard errors (S.E.). Student's $t$-test and chi-square test were used for a statistical comparison between the groups.

\section{RESULTS}

Effects on homologous and heterologous PCA in guinea pigs: Control wheal sizes of the homologous 8-day PCA induced by IgE-like antibody and the homologous 3-hr PCA induced by IgG antibody were $190 \pm 6$ and $217=19 \mathrm{~mm}^{2}$, respectively. AA-344 (20 mg/kg i.v.) given immediately before the antigen challenge significantly suppressed both the PCAs. DSCG (5 and $20 \mathrm{mg} / \mathrm{kg}$ i.v.) showed no significant inhibitory effects (Table 1). Similar effects of both compounds were also observed when the 8-day and 3-hr PCAs were provoked in the animals sensitized with the 4-fold higher concentration of the antisera. The heterologous PCA showing wheal size of $181 \pm 27 \mathrm{~mm}^{2}$ was not inhibited by AA-344 or DSCG ( 5 and $20 \mathrm{mg} / \mathrm{kg}$ i.v.) given immediately before the antigen challenge (Table 1).

Effects on PSA in guinea pigs and ASA in mice: The antigen challenge to guinea pigs sensitized passively with i.v. administration of rabbit anti-EA, resulted in symptoms of grade III in 24 and death in 23 out of 27 animals, within 30 min after the antigen challenge. AA-344 $(5 \mathrm{mg} / \mathrm{kg}$ i.v.) given immediately before the antigen challenge decreased the mortality, though it did not alleviate the symptoms. However, a high dose of AA-344 (20 mg/ $\mathrm{kg}$ i.v.) markedly alleviated the symptoms in 10 out of 18 animals and prevented death in all animals (Table 2). The same doses of DSCG had no effect on the anaphylactic shock. Promethazine ( $1 \mathrm{mg} / \mathrm{kg}$ i.v.) markedly reduced symptoms of the PSA. The intravenous challenge of antigen (EA) to the sensitized mice resulted in death of 19 out of 20 mice within $30 \mathrm{~min}$ (Table 2). The ASA was not alleviated by AA-344 or DSCG (5 and $20 \mathrm{mg} / \mathrm{kg}$ i.v.) given $5 \mathrm{~min}$ before the challenge. Cyproheptadine $(1 \mathrm{mg} / \mathrm{kg}$ i.v. $)$ significantly reduced the mortality due to the ASA.

Effects on passive Schultz-Dale reaction in guinea pigs: Before and after each test, the

TABLE 1. Effects of AA-344 and DSCG on homologous 8-day and 3-hr PCA reactions and on heterologous 3-hr PCA reaction in guinea pigs

\begin{tabular}{lcccccc}
\hline \multirow{2}{*}{ Drugs } & $\begin{array}{c}\text { Dose } \\
\text { (mg/kg i.v.) }\end{array}$ & \multicolumn{2}{c}{ Homologous PCA, $\mathrm{mm}^{2}$} & \multicolumn{2}{c}{ Heterologous PCA, $\mathrm{mm}^{2}$} \\
\cline { 3 - 7 } & $\begin{array}{c}\text { No. of } \\
\text { animals }\end{array}$ & 8 -day & $3-\mathrm{hr}$ & $\begin{array}{c}\text { No. of } \\
\text { animals }\end{array}$ & 3 -hr \\
\hline Saline & - & 6 & $190 \pm 6$ & $217 \pm 19$ & 5 & $181 \pm 27$ \\
AA-344 & 5 & 5 & $193 \pm 14$ & $193 \pm 12$ & 5 & $173 \pm 31$ \\
& 20 & 6 & $141 \pm 20^{* *}$ & $134 \pm 15^{* *}$ & 5 & $169 \pm 21$ \\
DSCG & 5 & 5 & $178 \pm 24$ & $213 \pm 29$ & 5 & $167 \pm 22$ \\
& 20 & 6 & $202 \pm 21$ & $246 \pm 17$ & 5 & $178 \pm 13$ \\
\hline
\end{tabular}

**P $<0.01$ vs. saline control group. 
TABLE 2. Effects of AA-344, DSCG, promethazine and cyproheptadine on passive systemic anaphylaxis (PSA) in guinea pigs and on active systemic anaphylaxis (ASA) in mice

\begin{tabular}{|c|c|c|c|c|c|c|c|}
\hline \multirow{3}{*}{ Drugs } & \multirow{3}{*}{$\begin{array}{c}\text { Dose } \\
(\mathrm{mg} / \mathrm{kg} \mathrm{i.v.})\end{array}$} & \multicolumn{5}{|c|}{ PSA in guinea pigs } & \multirow{3}{*}{$\frac{\text { ASA in mice }}{\text { Mortality }}$} \\
\hline & & \multicolumn{4}{|c|}{ Symptoms, No. of animals } & \multirow{2}{*}{$\frac{\text { Mortality }}{\text { Died/Total }}$} & \\
\hline & & 0 & I & II & III & & \\
\hline Saline & - & 0 & 0 & 3 & 24 & $23 / 27$ & $19 / 20$ \\
\hline \multirow[t]{2}{*}{ AA-344 } & 5 & 0 & 0 & 3 & 13 & $8 / 16^{*}$ & $19 / 19$ \\
\hline & 20 & 2 & 8 & 7 & 1 & $0 / 18^{* *}$ & $18 / 19$ \\
\hline \multirow[t]{2}{*}{ DSCG } & 5 & 0 & 0 & 3 & 13 & $13 / 16$ & $18 / 20$ \\
\hline & 20 & 0 & 2 & 1 & 13 & $13 / 16$ & $17 / 19$ \\
\hline Promethazine & 1 & 0 & 3 & 12 & 1 & $0 / 16^{* *}$ & - \\
\hline Cyproheptadine & 1 & - & - & - & - & - & $2 / 9^{*}$ \\
\hline
\end{tabular}

${ }^{*} \mathrm{P}<0.05 ; \quad{ }^{* *} \mathrm{P}<0.01$ vs. saline control group.

TABLE 3. Effects of AA-344, DSCG and diphenhydramine on passive Schultz-Dale reaction in guinea pigs

\begin{tabular}{lcccc}
\hline Drugs & $\begin{array}{c}\text { Conc. } \\
\text { (M) }\end{array}$ & N & \multicolumn{2}{c}{ Schultz-Dale reaction ${ }^{\mathfrak{z})}$} \\
\hline AA-344 & $10^{-5}$ & 5 & Saline & Drug \\
& $10^{-1}$ & 5 & $101 \pm 10$ & $94 \pm 12$ \\
\multirow{3}{*}{ DSCG } & $10^{-3}$ & 5 & $101 \pm 10$ & $91 \pm 11$ \\
& $10^{-5}$ & 5 & $102 \pm 9$ & $75 \pm 14$ \\
\multirow{2}{*}{ Diphenhydramine } & $10^{-4}$ & 5 & $102 \pm 9$ & $99 \pm 11$ \\
& $10^{-3}$ & 5 & $102 \pm 9$ & $115 \pm 11$ \\
& $10^{-7}$ & 3 & $112 \pm 8$ & $113 \pm 12$ \\
& $10^{-6}$ & 3 & $103 \pm 12$ & $2 \pm 1 * *$ \\
\hline
\end{tabular}

a) $\%$ contraction height, compared with the histamine response $\left(2.5 \times 10^{-7} \mathrm{M}\right)$.

${ }^{* * *} \mathbf{P}<0.001$ vs. saline treated group.

responsiveness of the isolated guinea pig ileum passively sensitized with rabbit anti-EA was checked with histamine as a spasmogen. A challenge with an optimal concentration of antigen $\left(10^{-4} \mathrm{~g} \mathrm{EA} / \mathrm{ml}\right)$ provoked a rapid contractile response followed by a slow contractile response of the sensitized ileum. The height of the rapid contraction was submaximal, that is similar to the contractile response to histamine $\left(2.5 \times 10^{-7} \mathrm{M}\right)$. In this study, a decrease in the height of the rapid contractile response was used as a measure of evaluation. AA-344 $\left(10^{-5}\right.$ and $10^{-4} \mathrm{M}$ ) added $2 \mathrm{~min}$ before the challenge had no effect on the passive Schultz-Dale reaction (Table 3 ), but with a high concentration of AA-344 $\left(10^{-3} \mathrm{M}\right)$ a slight inhibition of the reaction was seen. On the contrary, DSCG $\left(10^{-5}\right.$ to $\left.10^{-3} \mathrm{M}\right)$ showed no inhibitory activity. Diphenhydramine $\left(10^{-6} \mathrm{M}\right)$ significantly depressed the reaction.

Effects on complement-dependent cytolysis of SRBC or RMC and on hypotonic cytolysis of SRBC (in vitro): The degree of the complement-dependent hemolysis of SRBC in vitro under the standard assay condition with rabbit anti-Forssman antigen antiserum was 47.2 
TABLE 4. Effects of AA-344 and DSCG on complement-dependent cytolyses of $\mathrm{SRBC}$ and $\mathrm{RMC}$ and on hypotonic cytolysis of SRBC (in vitro)

\begin{tabular}{|c|c|c|c|c|c|c|c|}
\hline \multirow[b]{2}{*}{ Drugs } & \multirow[b]{2}{*}{$\begin{array}{l}\text { Conc. } \\
\text { (M) }\end{array}$} & \multicolumn{4}{|c|}{ Complement-dependent cytolysis } & \multicolumn{2}{|c|}{ Hypotonic cytolysis } \\
\hline & & $\mathrm{N}$ & $\begin{array}{l}\text { SRBC } \\
\text { hemolysis }\end{array}$ & $N$ & $\begin{array}{l}\mathrm{RMC} \\
\text { release }\end{array}$ & $N$ & $\begin{aligned} & \text { SRBC } \\
\therefore & \text { hemolysis }\end{aligned}$ \\
\hline None & - & 5 & $47.2+3.8$ & 5 & $57.7 \div 3.0$ & 3 & 53.011 .0 \\
\hline \multirow[t]{3}{*}{ AA-344 } & $3 \cdot 10^{-1}$ & 4 & $43.9 \therefore 4.3$ & 5 & $57.4: 5.4$ & 3 & $48.5: 2.3$ \\
\hline & $1 \times 10^{-3}$ & 4 & $31.5-1.0^{* *}$ & 5 & $60.0 \_4.8$ & 3 & $43.3=4.8$ \\
\hline & $3 \times 10^{-3}$ & 4 & $11.0 \div 2.3 * * *$ & 5 & $38.1+6.5 *$ & 3 & $30.9 \div 2.2 * * *$ \\
\hline \multirow[t]{3}{*}{ DSCG } & $3 \therefore 10^{-1}$ & 4 & $44.5-4.6$ & 5 & $50.3 \therefore 4.4$ & 3 & $49.6 \ldots 3.0$ \\
\hline & $1 \times 10^{3}$ & 4 & $36.2=3.9$ & 5 & $35.8 \pm 3.0 * *$ & 3 & $45.5=3.1$ \\
\hline & $3 \times 10^{-3}$ & 4 & $7.8 \pm 3.2^{* * *}$ & 5 & $30.8 \pm 4.1 * *$ & 3 & $28.7 \pm 6.3^{*}$ \\
\hline
\end{tabular}

${ }^{*} \mathrm{P}<0.05 ; * * \mathrm{P}<0.01 ; * * * \mathrm{P}<0.001$ vs. non-treated group. The histamine release induced by rabbit anti-RMC antiserum and complement and the spontaneous histamine release were 57.7 $3 \%(\mathrm{n}=5)$ and $3.6-0.8 \%(\mathrm{n}=5)$ of the total histamine content in the mast cells $(15.3 \pm 0.6 \mathrm{qg}$ $10^{6}$ cells, $n=5$ ), respectively. The total histamine content was determined from the histamine released by boiling the sensitized cells for $15 \mathrm{~min}$.

$-3.8 \%$ (Table 4). Both AA-344 and DSCG $\left(0.3,1\right.$ and $\left.3 \times 10^{-3} \mathrm{M}\right)$ added simultaneously with complement showed a concentration-dependent inhibition of the hemolysis of SRBC. The degree of the complement-dependent cytolysis of the purified RMC with rabbit antiRMC expressed in terms of the released histamine, the released lactate dehydrogenase activity and the number of RMC stained with trypan blue were 59.8, 62.2 and $49.7 \%$, respectively. Under the same condition, AA-344 $\left(3 \times 10^{-3} \mathrm{M}\right)$ added simultaneously with complement significantly inhibited the cytolysis (Table 4). DSCG $\left(1\right.$ and $\left.3 \times 10^{-3} \mathrm{M}\right)$ also showed a significant inhibition. Experiment on the hypotonic cytolysis of SRBC shown in Table 4 was performed to evaluate a non-selective membranous stabilization such as that of anti-inflammatory drugs. The concentration of sodium chloride required to induce a hypotonic hemolysis of SRBC by approx. $50 \%$ was $65 \mathrm{mM}$. The high concentrations of AA-344 and DSCG similar to those used in the inhibition of the complement-dependent cytolysis of SRBC and RMC in vitro suppressed the NaCl-hypotonic cytolysis (Table 4). These results suggest that the inhibitory action of AA-344 and DSCG on the complement-dependent cytolysis may be related, at least partly, to the stabilizing activity on membrane.

Effects on Forssman shock in guinea pigs and on cytolysis of RMC in rats in vivo: The i.v. administration of rabbit anti-Forssman antigen antiserum in guinea pigs $(n=8)$ provoked the Forssman shock. All of the animals died within 3 min and the complement activity (CH50) was reduced by approx. 50\% (Table 5). AA-344, DSCG (5 and $20 \mathrm{mg} / \mathrm{kg}$ i.v.) and dexamethasone $(10 \mathrm{mg} / \mathrm{kg}$ i.v.) given immediately before the challenge had no effect on the shock or reduction of the complement activity. The degree of the complement-dependent cytolysis of RMC provoked by the i.p. administration of rabbit anti-RMC was expressed in terms of the reduction in the histamine content of the peritoneal cells harvested. The average histamine contents of the peritoneal cells in the rats treated with normal rabbit serum and rabbit anti-RMC $4 \mathrm{hr}$ before harvest of the cells were $40.9 \pm 1.1 \mu \mathrm{g}(\mathrm{n}=3)$ and $16.3 \pm 4.2$ 
$\mu \mathrm{g}(\mathrm{n}=6)$ per rat, respectively. AA-344 and DSCG (5 and $20 \mathrm{mg} / \mathrm{kg}$ i.v.) given immediately before the challenge had no effect, and dexamethasone showed a significant suppression of the cytolysis (Table 5).

Effects on Arthus reaction in guinea pigs: The Arthus reaction with hemorrhage and edema was provoked by the i.d. administration of antigen (EA) in guinea pigs passively sensitized with the i.v. administration of rabbit anti-EA. Eleven out of 12 animals treated with saline produced the Arthus reaction with the degree of severity + or higher, which was defined as positive (Table 6). In the histological study with hematoxylin-eosin staining, infiltration of polymorphonuclear leukocytes and monocytes around the blood vesesls in the lesion was observed. When the degree of severity of \pm to ++++ was converted into numeral scores of 1 to 5 , the average score in the saline-treated animals was 3.3. AA-344 ( 5 and $20 \mathrm{mg} / \mathrm{kg}$ i.v.) given immediately before the antigen challenge slightly reduced the

TABLE 5. Effects of AA-34, DSCG and dexamethasone on Forssman shock in guinea pigs and on cytolysis of RMC in rats given i.p. rabbit anti-RMC antiserum

\begin{tabular}{|c|c|c|c|c|c|c|c|c|c|}
\hline \multirow{3}{*}{ Drugs } & \multirow{3}{*}{$\begin{array}{c}\text { Dose } \\
\text { (mg/kg } \\
\text { i.v.) }\end{array}$} & \multirow{3}{*}{$\mathrm{N}^{n}$} & \multicolumn{5}{|c|}{ Forssman shock in guinea pigs } & \multirow{3}{*}{$\mathrm{N}$} & $\begin{array}{l}\text { Cytolysis } \\
\text { of } \mathrm{RMC}\end{array}$ \\
\hline & & & \multirow[b]{2}{*}{$\begin{array}{c}\text { Mortality } \\
(\%)\end{array}$} & \multirow{2}{*}{$\begin{array}{c}\text { Survival } \\
\text { time } \\
\text { (sec) }\end{array}$} & \multicolumn{3}{|c|}{ Complement activity, $\mathrm{CH} 50^{\mathrm{b}}$} & & \multirow{2}{*}{$\begin{array}{l}\text { Histamine } \\
\text { content of } \\
\text { peritoneal } \\
\text { cells } \\
(\mu \mathrm{g} / \mathrm{rat})\end{array}$} \\
\hline & & & & & $\begin{array}{c}\text { Before } \\
\text { challenge }\end{array}$ & $\begin{array}{l}\text { After } \\
\text { death }\end{array}$ & $\begin{array}{l}\text { De- } \\
\text { crease } \\
(\%)\end{array}$ & & \\
\hline Saline & - & 8 & 100 & $121+43$ & $139.3 \pm 11.6$ & $74.1 \pm 4.7$ & 47 & 6 & $16.3 \pm 4.2$ \\
\hline \multirow[t]{2}{*}{ AA -344} & 5 & 8 & 100 & $112+45$ & $137.8 \pm 5.1$ & $58.7 \pm 10.4$ & 57 & 3 & $14.4 \pm 2.1$ \\
\hline & 20 & 8 & 100 & $147 \pm 40$ & $149.6 \pm 12.5$ & $80.0 \pm 7.7$ & 47 & 3 & $19.4 \pm 8.7$ \\
\hline DSCG & 20 & 7 & 100 & $108 \pm 14$ & $167.6 \pm 23.7$ & $88.5 \pm 13.8$ & 47 & 3 & $20.1 \pm 5.1$ \\
\hline Dexamethasone & 10 & 8 & 100 & $121 \pm 1$ & $124.0 \pm 10.8$ & $72.0 \pm 7.8$ & 42 & 3 & $26.5 \pm 2.7^{*}$ \\
\hline
\end{tabular}

a) $\mathrm{N}$ : Number of animals. b) $\mathrm{CH} 50: 50 \%$ hemolytic unit of complement. ${ }^{*}: \mathrm{P}<0.05$

TABLE 6. Effects of AA-344, DSCG and dexamethasone on passive Arthus reaction in guinea pigs

\begin{tabular}{|c|c|c|c|c|c|c|c|c|c|c|}
\hline \multirow{2}{*}{ Drugs } & \multirow{2}{*}{$\begin{array}{c}\text { Dose } \\
(\mathrm{mg} / \mathrm{kg}, \text { i.v. })\end{array}$} & \multirow{2}{*}{$\begin{array}{l}\text { No. of } \\
\text { animals }\end{array}$} & \multicolumn{8}{|c|}{ Severity of Arthus reaction } \\
\hline & & & $++t+$ & +++ & ++ & + & \pm & - & $\begin{array}{l}\text { Mean } \\
\text { score }\end{array}$ & $\begin{array}{c}\text { Positive } \\
(\geqq+)\end{array}$ \\
\hline Saline & - & 12 & 4 & 1 & 2 & 4 & 1 & 0 & 3.3 & $11 / 12$ \\
\hline \multirow[t]{2}{*}{ AA-344 } & 5 & 11 & 3 & 1 & 2 & 2 & 1 & 2 & 2.7 & $8 / 11$ \\
\hline & 20 & 11 & 2 & 1 & 1 & 2 & 3 & 2 & 2.2 & $6 / 11$ \\
\hline \multirow[t]{2}{*}{ DSCG } & 5 & 11 & 1 & 2 & 0 & 6 & 1 & 1 & 2.4 & $9 / 11$ \\
\hline & 20 & 11 & 2 & 3 & 1 & 5 & 0 & 0 & 3.2 & $11 / 11$ \\
\hline Dexamethasone & 10 & 10 & 0 & 0 & 1 & 4 & 4 & 1 & 1.5 & $5 / 10$ \\
\hline
\end{tabular}

Grade: ++++ ; A confluent hemorrhage of $10 \mathrm{~mm}$ or more in length (longest axis) with severe edema at $2 \mathrm{hr}$, and a hemorrhagic discoloration of $10 \mathrm{~mm}$ in length and moderate to severe edema at $24 \mathrm{hr} .++$; A petechial hemorrhage of $15 \mathrm{~mm}$ in length with moderate to severe edema at $2 \mathrm{hr}$, and a discoloration of 5 to $10 \mathrm{~mm}$ in length with moderate edema at $24 \mathrm{hr}$. ++ ; A petechial hemorrhage of 10 to $15 \mathrm{~mm}$ in length with moderate edema at $2 \mathrm{hr}$, and a discoloration of $5 \mathrm{~mm}$ in length with mild to moderate edema at $24 \mathrm{hr}$. +; A mild edema, petechial hemorrhage of 5 to $10 \mathrm{~mm}$ in length at $2 \mathrm{hr}$, and the reaction was still visible at $24 \mathrm{hr}$. \pm ; A petechial hemorrhage of less than $5 \mathrm{~mm}$ in length with slight or no edema at $2 \mathrm{hr}$. Negative at $24 \mathrm{hr}$. -; No reaction. 
TABLF 7. Effects of AA-344, DSCG and dexamethasone on tuberculin reaction and contact sensitivity in mice

\begin{tabular}{|c|c|c|c|c|}
\hline \multirow{2}{*}{ Drugs } & \multirow{2}{*}{$\underset{(\mathrm{mg} / \mathrm{kg}, \text { i.p. })}{\text { Dose }}$} & \multirow{2}{*}{$\begin{array}{l}\text { No. of } \\
\text { mice }\end{array}$} & Tuberculin reaction & \multirow{2}{*}{$\begin{array}{c}\text { Contact sensitivity } \\
\text { Increase in ear thickness } \\
\times 10^{-2} \mathrm{~mm}\end{array}$} \\
\hline & & & $\begin{array}{l}\text { Footpad swelling } \\
\times 10^{-2} \mathrm{~mm}\end{array}$ & \\
\hline $5 \%$ gum arabic & - & 8 & $118.8 \div 9.0$ & $7.9+0.8$ \\
\hline \multirow[t]{2}{*}{ AA-344 } & 5 & 8 & $107.6 \div 12.3$ & $6.9 \therefore 0.6$ \\
\hline & 20 & 8 & $136.1 \div 22.2$ & $7.2+0.6$ \\
\hline \multirow[t]{2}{*}{ DSCG } & 5 & 8 & 136.410 .3 & $6.8 \div 0.7$ \\
\hline & 20 & 8 & $117.1 \div 11.1$ & $6.9 \bigcirc 0.7$ \\
\hline Dexamethasone & 5 & 8 & $63.8-5.9^{* *}$ & $3.9 \therefore 0.5^{* *}$ \\
\hline
\end{tabular}

Drugs were administered i.p. $30 \mathrm{~min}$ before the challenge. Swelling of footpads measured $24 \mathrm{hr}$ after the challenge was expressed as the difference in thickness between the right footpad (saline) and left footpad (PPD). ${ }^{* *}: \mathrm{P}<0.01$

number of positive responses and the score. The same doses of DSCG hardly affected the Arthus reaction. Dexamethasone $(10 \mathrm{mg} / \mathrm{kg}$ i.v.) reduced considerably but not significantly the degree of severity and the score of the Arthus reaction.

Effects on tuberculin reaction and contact sensitivity in mice: The tuberculin reaction in mice sensitized with killed Mycobacterium tuberculosis and FIA was provoked by the challenge of PPD. The footpad swelling $24 \mathrm{hr}$ after the challenge was approx. $120 \times 10^{-2} \mathrm{~mm}$ as measured using a thickness gauge (Table 7). AA-344 and DSCG ( 5 and $20 \mathrm{mg} / \mathrm{kg}$ i.p.) given $30 \mathrm{~min}$ before the challenge showed no effect, whereas dexamethasone $(5 \mathrm{mg} / \mathrm{kg}$ i.p.) significantly suppressed the reaction. In non-sensitized mice, the increment of the ear thickness at $24 \mathrm{hr}$ after the application of DNFB was $0.9 \times 10^{-2} \mathrm{~mm}$. However, in the sensitized mice, the increment of the ear thickness $24 \mathrm{hr}$ after the challenge of DNFB was $7.9 \times 10^{-2} \mathrm{~mm}$ (Table 7). Dexamethasone $(5 \mathrm{mg} / \mathrm{kg}$ i.p.) given $30 \mathrm{~min}$ before the challenge of DNFB significantly suppressed the reaction, but AA-344 and DSCG (5 and $20 \mathrm{mg} / \mathrm{kg}$ i.p.) had no effect on the contact sensitivity to DNFB.

\section{DISCUSSION}

Our previous work showed that AA-344 as well as DSCG markedly inhibited the IgE-mediated PCA in rats (1) and that the antiallergic action is due to the prevention of the chemical mediator release from the mast cells (2). In the work reported herein, the homologous 8-day PCA in guinea pigs, which is reportedly induced by the antiserum containing IgE-like antibody $(9,21)$, was significantly inhibited by AA-344. The antiserum used in the present experiment showed the following IgE-like characteristics: presence of the PCA activity for more than 8 days, a partial but significant thermolability at $56^{\circ} \mathrm{C}$ for $4 \mathrm{hr}$, and a complete inactivation by alkylation with iodoacetamide following reduction with 2-mercaptoethanol. These properties were similar to those of human IgE antibody characterized by Ishizaka and Ishizaka (22), the rat IgE antibody reported by Stechshulte et al. (23), and the guinea pig antibody observed by Levine et al. (9). The role of mast cells on the 8-day PCA in guinea pigs has also been considered to be the same as that on the IgE-mediated 
PCA in rats (24). All these findings taken together suggest that the mode of the inhibitory action of AA-344 on the 8-day PCA in guinea pigs was the same as that on the 72-hr PCA in rats. On the other hand, the homologous 3-hr PCA in guinea pigs provoked by the antiserum containing IgG antibody ( $\gamma_{1}$-antibody) was also inhibited by AA-344, similar to that on the IgGa-mediated PCA in rats reported previously (1). However, DSCG in doses of 5 and $20 \mathrm{mg} / \mathrm{kg}$ i.v. showed no inhibitory effect on both the 8-day PCA and 3-hr PCA in guinea pigs. Taylor and Roitt (25) reported that DSCG reduced the PCA reaction induced by IgE-like antibody in guinea pigs. However, Martin (26) detected no inhibitory action of DSCG on the IgE-like antibody-induced PCA in guinea pigs, such being in agreement with our present results. Furthermore, no inhibitory effect of DSCG on the 3-hr PCA induce 1 by $\gamma_{1}$-antibody in guinea pigs was observed by Cox et al. (4), Taylor and Roitt (25), and Lopez and Bloch (27).

The in vitro complement-dependent cytolysis of $\mathrm{SRBC}$ or RMC, as type II allergic reactions, was significantly inlibited by AA-344 and DSCG at the concentrations up to $10^{-3} \mathrm{M}$, but the in vivo reactions of the Forssman shock in guinea pigs and the cytolysis of RMC in rats were not affected by these compounds. The inhibitory action of AA-344 on the in vitro type II allergic reaction may be related, at least in part, to the non-specific membranous stabilization similar to that seen with anti-inflammatory drugs, because AA-344 possessed a preventive action regarding the cytolysis of SRBC, as induced by hypotonic treatment in vitro.

Regarding the passive Arthus reaction in guinea pigs as the experimental model of the type III allergic reaction, AA-344 was found to slightly alleviate the symptoms characterized by hemorrhage. The Arthus reaction in rabbits was reported to proceed in two stages, i.e., the maximum dye leakage in the lesions was attained at both $30 \mathrm{~min}$ and $5 \mathrm{hr}$ after the challenge with antigen (28). The early reaction was reduced by antihistamines while the late reaction was not, suggesting the involvement of histamine in development of the early reaction. Cochrane (29) suggested the participation of IgE, IgG, basophilic leukocytes or mast cells in the early stage of the immune complex disease (serum sickness) in rabbits. Koda et al. (30) demonstrated a moderate inhibitory action of $\mathrm{N}\left(3^{\prime}, 4^{\prime}\right.$-dimethoxycinnamoyl)anthranilic acid on the Arthus reaction in rabbits. This compound was also reported to possess inhibitory activity on the release of histamine from the mast cells and the antiinflammatory activity on the rat carrageenin edema (31). These observations suggest that increase in the permeability of vessels caused by type I allergic mechanism may be involved in the early stage of the Arthus reaction. If AA-344 actually suppresses the Arthus reaction, the mode of action may be associated with inhibition of the chemical mediator release from mast cells. However, DSCG did not inhibit the reaction, in the present study. The reported clinical effectiveness of DSCG on type III late asthmatic reaction provoked experimentally by inhalation of antigen (5-7), should therefore be examined further. On the other hand, Fishel (32) and Waksman (33) reported that treatment with an antihistamine failed to inhibit the rabbit homologous passive Arthus reaction. Therefore, a further study to analyze the immunological mechanism of the Arthus reaction may be a prerequisite to determine the 
appropriateness of this reaction as an attempt to evaluate the antiallergic agent.

Increase in the vascular permeability in the delayed hypersensitivity as in the tuberculin reaction and the contact sensitivity is considered to be caused by lymphokines from the lymphocytes (34-36). However, Gershon et al. (37) proposed that the release of vasoactive amines from mast cells provided a modulation for the development of contact sensitivity and the footpad reaction in mice, as inhibited by pretreatment with reserpine. Additional evidence is required, however, for an accurate interpretation of the results as reserpine has various systemic effects. Neither AA-344 nor DSCG exerted an inhibitory action on the tuberculin reaction and the contact sensitivity to DNFB in mice.

Acknowledgements: We are greatly indebted to Drs. K. Shimamoto, Y. Nagawa and M. Kanno for pertinent suggestions and discussions. We thank Miss M. Nakahara and Mr. K. Gomaibashi for technical assistance and Dr. C.L. Huang for help with the manuscript.

\section{REFERENCES}

1) Kuriki, H., Saijo, T., Maki, Y. and Kanno, M.: Antiallergic action of 6-ethyl-3-(1Htetrazol-5-yl)chromone (AA-344) on immediate hypersensitivity reaction in rats. Japan. J. Pharmacol. 29, 385-397 (1979)

2) Saijo, T., Ashida, Y., Kuriki, H., Kanno, M. and MaKi, Y.: Inhibitory action of 6-ethyl3-(1H-tetrazol-5-yl)chromone (AA-344) on IgE-, IgGa- or chemical agent-induced histamine release from isolated rat mast cells. Japan. J. Pharmacol. 29, 531-540 (1979)

3) Brogden, R.N., Speight, T.M. And Avery, G.S.: Sodium cromoglycate (cromolyn sodium): A review of its mode of action, pharmacology, therapeutic efficacy and use. Drugs 7 , 164-282 (1974)

4) Cox, J.S.G., Beach, J.E., Blair, A.M.J.N., Clarke, A.J., King, J., Lee, T.B., Loveday, D.E.E., Moss, G.F., Orr, T.S.C., Ritchie, J.T. and Sheard, P.: Disodium cromoglycate (Intal ${ }^{\text {Kk }}$ ). Adv. Drug Res. 5, 115-196 (1970)

5) Pepys, J., Hargreave, F.E., Chan, M. and McCarthy, D.S.: Inhibitory effects of disodium cromoglycate on allergen-inhalation tests. Lancet ii, 134-137 (1968)

6) BoOIJ-NoORd, H., ORIE, N.G.M. AND dE VRIES, K.: Immediate and late bronchial obstructive reactions to inhalation of house dust and protective effects of disodium cromoglycate and prednisolone. J. Allergy clin. Immunol. 48, 344-354 (1971)

7) Molk, L.: Blocking of induced asthma by cromolyn sodium. Ann. Allergy 30, 321-325 (1972)

8) Horiuchi, Y. and Shibata, K.: Immunochemical studies on the antigenic bindings of benzylpenicillin and five synthetic penicillins with proteins. Int. Archs Allergy appl. Immunol. 28, 306-320 (1965)

9) Levine, B.B., Chang, H. And Vaz, N.M.: The production of hepten-specific reaginic antibodies in the guinea pig. J. Immunol. 106, 29-33 (1971)

10) Koda, A., NAGal, H. AND WAdA, H.: Pharmacological actions of baicalin and bicalein. (Report i) On the active anaphylaxis. Folia pharmacol. japon. 66, 194-213 (1970) (Abs. in English)

11) UdA, A.: Anti-anaphylactic effect of guaiazulene in the guinea pig. Folia pharmacol. japon. 54, 930-939 (1958) (Abs. in English)

12) Greig, M.E., Gibbons, A.J. and Young, G.A.: The antiallergy properties of U-17,660, a dibenzodiazepine. Archs int. Pharmacodyn. Thér. 190, 299-308 (1971)

13) NishiokA, K.: Preparation of rabbit antibody to sheep red blood cells. Protein, Nucleic Acid and Enzyme 11, 1485-1486 (1966) (in Japanese)

14) Mayer, M.M.: Complement and complement fixation. Experimental Immunochemistry, 2nd ed. Edited by Kabat, E.A. ANd MaYer, M.M., p. 133-240, Charles C. Thomas Publisher, Springfield, Illinois (1961)

15) Sullivan, T.J., Parker, K.L., Stenson, W. and Parker, C.W.: Modulation of cyclic AMP 
in purified rat mast cells. I. Responses to pharmacologic, metabolic, and physical stimuli. J. Immunol. 114, 1473-1479 (1975)

16) YiU, S.H. AND Froese, A.: Characterization of an antiserum specific for cell surface antigens of rat mast cells. J. Immunol. 117, 269-273 (1976)

17) Valentine, M.D., Bloch, K.J. And Austen, K.F.: Mechanisms of immunologic injury of rat peritoneal mast cells. III. Cytotoxic histamine release. J. Immunol. 99, 98-110 (1967)

18) Shorf, P.A., Burkhalter, A. And Cohn, V.H.: A method for the fluorometric assay of histamine in tissues. J. Pharmacol. exp. Ther. 127, 182-186 (1959)

19) Benacerraf, B. and Kabat, E.A.: A quantitative study of the Arthus phenomenon induced passively in the guinea pig. J. Immunol. 64, 1-19 (1950)

20) Phanuphak, P., Moorhead, J.W. and Claman, H.N.: Tolerance and contact sensitivity to DNFB in mice. I. In vivo detection by ear swelling and correlation with in vitro cell stimulation. J. Immunol. 112, 115-123 (1974)

21) Perini, A. AND Mota, I.: Heterogeneity of guinea-pig homocytotropic antibodies. Immunology 22, 915-923 (1972)

22) IshizAKA, T. AND IsHizAKA, K.: Biology of immunoglobulin E. Molecular basis of reaginic hypersensitivity. Prog. Allergy 19, 60-121 (1975)

23) Stechschulte, D.J., Orange, R.P. and Austen, K.F.: Immunochemical and biologic properties of rat IgE. I. Immunochemical identification of rat IgE. J. Immunol. 105, $1082-1086(1970)$

24) Pearce, F.L., Behrendt, H., Blum, U., Poblete-Freundt, G., Pult P., Stang-Voss, Ch. AND SChmutzler, W.: Isolation and study of functional mast cells from lung and mesentery of the guinea pig. Agents and Actions 7, 45-56 (1977)

25) TAYLOR, W.A. AND ROITT, I.M.: Effect of disodium cromoglycate on various types of anaphylactic reaction in the guinea pig. Int. Archs Allergy appl. Immunol. 45, 795-807 (1973)

26) MARTIN, L.E.: Inhibition of cellular anaphylaxis by beta-stimulants. Post-grad. med. J. 47, Supp. p. 26-30 (1971)

27) LOPEZ, M. AND BLOCH, K.J.: Effect of disodium cromoglycate on certain passive cutaneous anaphylactic reactions. J. Immunol. 103, 1428-1430 (1969)

28) Hayashi, H., Yoshinaga, M., Koono, M., Miyoshi, H. and Matsumura, M.: Endogeneous permeability factors and their inhibitors affecting vascular permeability in cutaneous Arthus reactions and thermal injury. Brit. J. exp. Pathol. 45, 419-435 (1964)

29) Cochrane, C.G.: Mechanisms involved in the deposition of immune complexes in tissues. J. exp. Med. 134, 75s-89s (1971)

30) Koda, A., Nagai, H., Watanabe, S., Yanagihara, Y. and Sakamoto, K.: Inhibition of hypersensitivity reactions by a new drug, $N\left(3^{\prime}, 4^{\prime}\right.$-dimethoxycinnamoyl $) a n t h r a n i l i c$ acid (N-5'). J. Allergy clin. Immunol. 57, 396-407 (1976)

31) Azuma, H., Banno, K. and Yoshimura, T.: Pharmacological properties of N-(3',4'dimethoxycinnamoyl)anthranilic acid $\left(\mathrm{N}-5^{\prime}\right)$, a new anti-atopic agent. Brit. J. Pharmacol. 58, 483-488 (1976)

32) FISCHFL, E.E.: Effect of salicylate and tripelennamine hydrochloride (pyribenzamine) on the Arthus reaction and on bacterial allergic reactions. Proc. Soc. exp. Biol. Med. 66, 537-541 (1947)

33) Waksman, B.H.: Local phenomena of Arthus type. Atlas of experimental Immunobiology and Immunopathology, p. 35-36, Yale University Press, New Haven and London (1970)

34) BENNETT, B. AND BLoOM, B.R.: Reactions in viro and in vitro produced by a soluble substance associated with delayed-type hypersensitivity. Proc. natn. Acad. Sci. U.S.A. 59, 756-762 (1968)

35) Dumonde, D.C., Wolstencroht, R.A., Panayi, G.S., Matthew, M., Morley, J. and Howson, W.T.: "Lymphokines"; Non-antibody mediators of cellular immunity generated by lymphocyte activation. Nature 224, 38-42 (1969)

36) David, J.R. AND DAVID, R.R.: Cellular hypersensitivity and immunity. Inhibition of macrophage migration and the lymphocyte mediators. Prog. Allergy 16, 300-449 (1972) 
37) Gershon, R.K., Askenase, P.W. and Gershon, M.D.: Requirement for vasoactive amines for production of delayed-type hypersensitivity skin reactions. J. exp. Med. 142, 732-747 (1975) 